(Emory University) further stressed the complementarity of religion, art and philosophy in Hegel's system. All three worked towards the liberation of absolute consciousness. Both Desmond's and Verene's accounts left one wondering: why then Hegel had broken with Schelling's vicw of art as the absolute?

The final paper of the conference on 'Speculation and theonomy at the close of I Iegel's system' was given by Martin DeNys (George Mason University). 1)eNys brought out the important role which Hegel belicved negativity to play in the Christian religion. Hegel sees Christianity as picturing the limited and dependent position of the individual and then overcoming this alienation through the image of the unification of the human with the divine. But for $\mathrm{Hegel}$, DeNys argued, religious consciousness does not represent full self-consciousness because the main categories of religion come to the individual not as his own but in the form of a creed. Only philosophy can retrieve the full speculative worth of religion. L. Dupre (Yale University) in his commentary further stressed this aspect of Hegel's philosophy. Whereas Desmond's paper had sought to see all the forms of absolute spirit (art, religion and philosophy) as equivalent, Dupré argued that religion represented a less complete conceptualisation of the role of spirit. Geist, in Duprés view, should be seen as a continuous process of transcendence.

Howard Williams

The University College of Wales

Aberystwyth

\title{
HSGB Council Meeting
}

A meeting of the HSGB Council was held in Pembroke College, Oxford on 29 November 1984. The principal matter discussed was how to improve the appearance of the Bulletin by the use of clearer type and better printing technique. The financial situation of the Society according to the Treasurer allows extra expenditure for the purpose. The meeting also discussed ways to cope with the growing number of Hegel books sent to the Editor. (ireater use of short 'book notes' to review less valuable books or those of less central concern to the Bullesin readers, and a new section books received were suggested. Robert Bernasconi of The Philosophy Dept., Essex University, has agreed to help with future issues as Assistant Editor. 
The Council agreed to nominate Professor W.H. Walsh for clection as President of the HSGB in succession to Professor Raymond Plant who has indicated his intention to resign at the $198 \mathrm{~s}$ conference. Finally, the mecting also discussed plans for the $198 \mathrm{~s}$ HSGB Conference which Z.A. Pelczynski has undertaken to organize since W.H. Walsh is likely to be away at the time.

\section{I985 HSGB Conference: Notice}

Seventh Annual Conference of the HSGB will take place at Pembroke College, Oxford, on Thursday, 12 th and Friday, 13 th September $198 \mathrm{~s}$. The first session will be at 5 p.m. (after tea). The subject of the Conference will be Hegel's Philosophy of Right. The organizer and chairman of the conference will be Dr Z.A. Pelczynski and the Conference Secretary, Dr David Lamb. The cost for overnight accommodation and

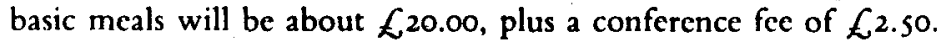

\section{Hegel Society of America}

1986 Conference on Hegel and his critics:

Philosophy in the aftermath of Hegel

First call for papers

TyF Hegel Society of America will hold its ninth biennial mecting at Enory University, Atlanta, Georgia, on October 9 11, 1986. Papers for reading should primarily focus on the argumentative substance of Hegel's views, and how these bear up under the charges of his major crities. Preference will be given to papers which explore the resources of Hegel's thought to answer the justice of these charges and to contribute to continuing philosophical debates. Papers for the mecting should not cxeced 30 inimutes reading time, and should be submitted for consiteration in this 